\title{
Genotoxicity and Mutagenicity Assays for Selection of Chemical Compounds with Therapeutic Potential: A Short Commentary
}

Silvany de Sousa Araujo ${ }^{2}$, Ana Maria Benko-Iseppon ${ }^{1}$ and Ana Christina Brasileiro-Vidal ${ }^{1 *}$

${ }^{1}$ Department of Genetics, Federal University of Pernambuco (UFPE), Recife, Pernambuco, Brazil

${ }^{2}$ Department of Physiology and Animal Morphology, Federal Rural University of Pernambuco (UFRPE), Recife, Pernambuco, Brazil

\section{Medicinal Plants}

During the last few decades, there has been a significant increase in the use and study of medicinal plants and their compounds for therapeutic applications. Secondary metabolites of different organisms have been a source of small organic molecules of outstanding chemical diversity, which are highly relevant for medicinal purposes [1]. However, in recent years, concerns about the poor quality control and the scientific evidence regarding the safety of such products have increased [2]. Randomized clinical testing of these products has revealed that undesirable side effects are possible and that many compounds can have toxic properties [3].These effects can affect vital processes such as DNA replication, gene transcription and cell division, leading to chromosomal abnormalities, cancerous processes, degenerative diseases and also cell death [4-6]. Pyrrolizidine alkaloids (PAs) and PA $\mathrm{N}$-oxides, for instance, identified as secondary metabolites have been detected in many traditional medicinal plants, including over 6000 specimens tested. On the other hand, PA can be considered as one of the main poisonous plant constituents for humans $[7,8]$. For example, in United States, toxic PAs were found in at least 28 traditional herbal medicines [8]. Among PA-containing plants, comfrey (Symphytum officinale) could be highlighted. Besides its use during over 2000 years for joint inflammation, tendon damage, gastrointestinal ulcerations and lung congestion among other treatments, comfrey has hepatotoxic, mutagenic and carcinogenic potential $[9,10]$. For this reason, many comfrey products have been banned from the market in United States and Canada $[8,9]$.

On the other hand, many populations are still largely dependent on plants for medicinal purposes [11,12]. In tropical countries, such natural resources are often sold in open markets based solely on their traditional use. For example in Brazil, an evaluation of phytoterapic products sold in market places and literature searches revealed that most of them (58.7\%) have never been studied regarding their compounds or potential risks [12]. Additionally, some herbs are easily confounded by its adulterants. The problem is that some herbs and/or their adulterants can also present side toxic effects [13]. For example, a recent study using MTT and Comet assays on HepG2 cells [14] evaluated the ethanolic extract of Euphorbia hyssopifolia widely used in South America and Asia due to its antimicrobial effects, uncovering that its extract is cytotoxic and/or genotoxic to human health even in small dosages $(\geq 0.01 \mathrm{mg} /$ $\mathrm{mL}$ ). Therefore, the correct identification of the medicinal herbs, the elucidation of side effects, appropriate doses, ways of extraction and conservation and toxic studies are the first challenges for a safety use of medicinal plants [15] and for further investigation.

\section{Genotoxicity and Mutagenicity Assays}

Genotoxicity is a term that refers to the ability to interact with DNA and/or the cellular apparatus that regulates the fidelity of the genome (i.e. DNA, spindle apparatus and enzymes involved in the maintenance of genome). On the other hand, mutagenicity refers to the induction of permanent transmissible changes in the structure of the genetic material of cells or organisms. These changes (mutations) can involve a single gene or a block of genes, such as a given chromosome segment [16]. In this regard, genotoxicity and mutagenicity tests are an important part of the assessment to the hazards of chemicals for regulatory purposes. To assess genotoxicity and/or mutagenicity, different possibilities must be considered: besides point mutations induction, a compound can induce changes in chromosome number (e.g. polyploidy or aneuploidy) or structure (e.g. breaks, deletions, rearrangements) $[17,18]$.

Important agencies such as International Conference on Harmonisation (ICH), The Organization for Economic Co-operation and Development (OECD), National Cancer Institute (NCI) and World Health Organization (WHO) have required safety tests for herbal medicines. Registration of pharmaceuticals requires a thorough assessment of their genotoxic potential. It is clear that no single test is capable of detecting all relevant genotoxic agents. Therefore, the usual approach should be to carry out a battery of in vitro and in vivo tests for genotoxicity. Such tests are complementary rather than representing different levels of hierarchy [19]. These agencies recommend: a test for gene mutation in bacteria; an in vitro test with cytogenetic evaluation of chromosomal damage with mammalian cells or an in vitro mouse lymphoma tk assay; and an in vivo test for chromosomal damage using rodent hematopoietic cells.

Bacteria are used in the most widely applied methods for detection of gene mutations. The bacterial reverse mutation test uses amino-acid requiring strains of Salmonella typhimurium and Escherichia coli to detect point mutations, which involve substitution, addition or deletion of one or a few DNA base pairs. The principle of this bacterial reverse mutation test is that it detects mutations, which reverts mutations present in the test strains and restore the functional capability of the bacteria to synthesize an essential amino acid. The revertant bacteria are detected by their ability to grow in the absence of the amino acid required by the parental test strain [20]. Salmonella assay, for instance, was used to identify the potential genotoxic of Senna alada extract, which is used in traditional medicine of many African countries for the treatment of microbial, inflammatory and stress-related diseases [21].

However, bacteria are evolutionarily distant from human model, lacking true nuclei and also enzymatic pathways to activate most promutagenic intermediates necessary to form mutagenic compounds. Therefore bacterial reverse mutation test may not be appropriate for

*Corresponding author: Ana Christina Brasileiro-Vidal, Department of Genetics, Federal University of Pernambuco (UFPE), Recife, Pernambuco, Brazil, Tel: +558121267816; E-mail: brasileirovidal.ac@gmail.com

Received: July 21, 2015; Accepted: September 04, 2015; Published September 07, 2015

Citation: Araujo SD, Benko-Iseppon AM, Brasileiro-Vidal AC (2015) Genotoxicity and Mutagenicity Assays for Selection of Chemical Compounds with Therapeutic Potential: A Short Commentary. Biochem Anal Biochem 4: 208. doi:10.4172/2161-1009.1000208

Copyright: $\odot 2015$ Araujo SD, et al. This is an open-access article distributed under the terms of the Creative Commons Attribution License, which permits unrestricted use, distribution, and reproduction in any medium, provided the original author and source are credited. 
the evaluation of certain classes of chemicals, for example highly bactericidal compounds (e.g. certain antibiotics) and those which are thought (or known) to interfere specifically with the mammalian cell replication system (e.g. some topoisomerase inhibitors and some nucleoside analogues). In such cases, mammalian mutation tests may be more appropriate [20].

In vitro chromosomal aberration test identify substances that cause structural chromosomal aberrations in cultured mammalian cells. Structural aberrations may be of two types, affecting chromosome or chromatid. Polyploidy (including endoreduplication) could also arise during in vitro chromosome aberration assays. Although aneugenic compounds can induce polyploidy, polyploidy alone does not indicate aneugenic potential and can simply indicate cell cycle perturbation or cytotoxicity. Thus, this test is not designed to measure aneuploidy. The in vitro chromosomal aberration test may employ cultures of established cell lines or primary cell cultures of human or rodent origin. The cells used should be selected on the basis of growth ability in culture, stability of the karyotype (including chromosome number) and spontaneous frequency of chromosomal aberrations [22].

The mammalian in vivo bone marrow chromosomal aberration test is especially relevant for assessing genotoxicity because, although they may vary among species, factors of in vivo metabolism, pharmacokinetics and DNA-repair processes are active and contribute to the responses. An in vivo assay is also useful for further investigation of genotoxicity detected by an in vitro system. Rodents are routinely used in this test, but other species may be appropriate in some cases if scientifically justified. Bone marrow is the target tissue in this test since it is a highly vascularized tissue and it contains a population of rapidly cycling cells that can be readily isolated and processed [23].

The mouse lymphoma TK assay (MLA) is usually part of an in vitro battery of tests developed to evaluate risk assessment prior to some in vivo tests. It has the potential to identify mutagenic and clastogenic episodes at the tk (thymidine kinase) locus of the L5178Y mouse lymphoma tk $( \pm)$ cells by accessing the resistance to the lethal nucleoside analogue triflurothymidine (TFT). This test is able to detect a wide spectrum of genetic events including point mutations (e.g. nucleotide substitution), intragenic and multilocus deletions, chromosomal rearrangements, nondisjunction and mitotic recombination. Two equally accepted versions of the assay can be used: (1) using soft agar cloning or (2) using liquid media cloning in 96-microwell plates. Two morphologically distinct types of MLA mutant colonies can be recovered: small- or large-colony mutants. The induction of small-colony mutants has been related with chemicals inducing large chromosomal aberrations whereas the induction of gross mutant colonies is generally correlated with chemicals that induce point mutations. Important variables that could influence the assay performance include the source and the karyotype of the cell line as well as the culture conditions. When performed according to the standards recommended by the International Workshops on Genotoxicity Testing, the assay is able to provide valuable genotoxicity hazard information as part of the overall safety assessment process of various classes of test substances [24].

Additional assays can be used to detect genotoxic effects using in vitro and in vivo cells. For example, in micronucleus test, for instance, an increase of micronucleated cells frequency in both in vitro and in vivo cells indicate the occurrence of chromosome damage(s), originated from chromosome fragmentation (clastogenic activity) and/ or whole chromosome loss (aneugenic activity, indicative of aneuploidy for the nucleus). Comparisons of micronucleus diameter also allow the determination of clastogenic or aneugenic potential of the compound tested [25]. However, more confidence in distinguishing between clastogenic or aneugenic micronuclei can be performed combining fluorescent in situ hybridization (FISH) technique with centromeric probes [26]. Besides, cytokinesis-block micronucleus cytome assay (CBMN-Cyt) is a variation of micronucleus test proposed by [27], in which once-divided cells are recognized by their binucleated $(\mathrm{BN})$ appearance after blocking cytokinesis with cytochalasin-B (Cyt-B) CBMN-Cyt allows the analysis of: (1) micronuclei frequencies, that can be used as a biomarker of both, chromosome breakage and whole chromosome loss (comparable to the classical micronucleus test); (2) nucleoplasmic bridge and nuclear bud frequencies, also generating a biomarker of DNA misrepair and/or telomere end-fusions, also leading to elimination of amplified DNA and/or DNA repair complexes, respectively; (3) cytostatic effects detectable by changes in the proportion of mono-, bi- and multinucleated cells; and (4) cytotoxicity via necrotic and/or apoptotic cell ratios [27].

Another effective tool for genotoxicity evaluation is the comet assay or 'Single Cell Assay Gel' (SCG), which is a very sensitive test and may be performed with any type of eukaryotic cell that can be individualized. The alkaline $(\mathrm{pH}>13)$ comet assay was developed by [28] and allows the detection of DNA single-strand breaks (SSB), alkalilabile sites (ALS), DNA-DNA or DNA-protein cross-linking and SSB related with incomplete excision repair sites. Among other genotoxicity tests, the major advantage of this last approach is its sensitivity for the detection of low levels of DNA damage $[18,29]$. These genotoxicity tests have been extensively used together or separately, to evaluate the genotoxic potential of extracts and compounds isolated from medicinal plants, since it allows a more complete assessment.

\section{Perspectives}

Currently, there is a public perception that all natural products are healthy and pose few or no risk, whereas man-made products may bring many side effects and risks. In fact, the opposite may occur, especially due to the lack of a specific dosage and the admixture of many compounds present in natural products [30]. Especially in tropical regions (where many non-tested phytoterapic products are preferred over commercial available drugs) there are still insufficient mechanisms of regulation on the market regarding dosage recommendations. Therefore, a greater body of scientific evidence uncovering the risks and benefits of natural products should be produced, collaborating to a safe maintenance of human health and protection from diseases. It is also important that scientific findings result in effective measures to control natural product commercialization, preventing public exposure to toxic and mutagenic products.

\section{References}

1. Arumugam R, Ragupathi Raja Kannan R, Jayalakshmi J, Manivannan $\mathrm{K}$ Karthikai Devi G, et al. (2012) Determination of element contents in herbal drugs: chemometric approach. Food Chem 135: 2372-2377.

2. Shin JW, Park HJ, Kwon M, Son CG (2010) Scientific evaluation of the chronic toxicity of the herbal medicine CGX in beagle dogs. Food Chem Toxicol 48: 743-749.

3. Nunes LG, Gontijo DC, Souza CJ, Fietto LG, Carvalho AF, et al. (2012) The mutagenic, DNA-damaging and antioxidative properties of bark and leaf extracts from Coutarea hexandra (Jacq.) K. Schum. Environ Toxicol Pharmacol 33: $297-303$

4. Belcavello L, Vencioneck Dutra JC, de Freitas JV, Aranha IP, do Carmo Pimentel Batitucci M (2012) Mutagenicity of ipriflavone in vivo and in vitro. Food Chem Toxicol 50: 996-1000.

5. Ouedraogo M, Baudoux T, Stevigny C, Nortier J, Colet J-M, et al. (2012) Review of current and "omics" methods for assessing the toxicity (genotoxicity, teratogenicity and nephrotoxicity) of herbal medicines and mushrooms. J Ethnopharmacol 140: 492-512. 
Citation: Araujo SD, Benko-Iseppon AM, Brasileiro-Vidal AC (2015) Genotoxicity and Mutagenicity Assays for Selection of Chemical Compounds with Therapeutic Potential: A Short Commentary. Biochem Anal Biochem 4: 208. doi:10.4172/2161-1009.1000208

6. Yuet Ping K, Darah I, Yusuf UK, Yeng C, Sasidharan S (2012) Genotoxicity of Euphorbia hirta: an Allium cepa assay. Molecules 17: 7782-7791.

7. Li N, Xia Q, Ruan J, Fu PP, Lin G (2011) Hepatotoxicity and tumorigenicity induced by metabolic activation of pyrrolizidine alkaloids in herbs. Curr Drug Metab 12: 823-834.

8. Roeder E, Wiedenfeld H, Edgar JA (2015) Pyrrolizidine alkaloids in medicinal plants from North America. Pharmazie 70: 357-367.

9. Rode D (2002) Comfrey toxicity revisited. Trends Pharmacol Sci 23: 497-499.

10. Mei N, Guo L, Fu PP, Heflich RH, Chen T (2005) Mutagenicity of comfrey (Symphytum Officinale) in rat liver. Br J Cancer 92: 873-875.

11. Benko-Iseppon AM, Crovella S (2010) Ethnobotanical bioprospection of candidates for potential antimicrobial drugs from Brazilian plants: state of art and perspectives. Curr Protein Pept Sci 11: 189-194.

12. Benko-Iseppon AM, Pinangé DSB, Chang SC, Morawetz W (2012) Ethnobotanical Uses of the Native Flora from Brazilian North-Eastern Region. In: Rai M, Cordell GA, Martinez MM, Rastrelli (eds). Medicinal Plants: Biodiversity and Drugs, CRC Press, 84-105.

13. Li M, Au KY, Lam H, Cheng L, But PP, et al. (2014) Molecular identification and cytotoxicity study of herbal medicinal materials that are confused by Aristolochia herbs. Food Chem 147: 332-339.

14. Araújo Sde S, Fernandes TC, Cardona YT, Almeida PM, Marin-Morales MA, et al. (2015) Cytotoxic and genotoxic effects of ethanolic extract of Euphorbia hyssopifolia L. on HepG2 cells. J Ethnopharmacol 170: 16-19.

15. Mendonça-Filho RR (2006) Bioactive Phytocompounds: New Approaches in the Phytosciences. In: Ahmad I, Aqil F, Owais M (eds) Modern Phytomedicine. Turning Medicinal Plants into Drugs. Wiley-VCH Verlag GmbH \& Co. KGaA Weinheim, 1-24.

16. Bragio S, Corsi M, Feriani A, Fontana S, Marocchio L, et al. (2014) Discovery Toxicology in lead Optimisation. In: Devis A, Ward SE. The Handbook of Medicinal Chemistry: Principles and Practice. Royal Society of Chemistry, Cambrigde, 364-406.

17. Salvador A, Chisvert A. Analysis of Cosmetics Products. Elsevier, Oxford. 475 pp. 2011.
18. Araújo SS, Fernandes TCC, Marin-Morales MA, Brasileiro-Vidal AC, BenkoIseppon AM (in press) Mutagenicity, genotoxicity and cytotoxicity assays of medicinal plants: first step for drug development. In: Duarte MCT, Rai M (eds). Therapeutic Medicinal Plants: From lab to the market, 130-153.

19. Food and Drug Administration, HHS (2012) International Conference on Harmonisation; guidance on S2(R1) Genotoxicity Testing and Data Interpretation for Pharmaceuticals intended for Human Use; availability. Notice. Fed Regist 77: 33748-33749.

20. OECD Guideline for Testing of Chemicals: Bacterial Reverse Mutation Test. Adopted: 21 July 1997

21. Hong CE, Lyu SY (2011) Genotoxicity detection of five medicinal plants in Nigeria. J Toxicol Sci 36: 87-93.

22. OECD Guideline for the Testing of Chemicals: In Vitro Mammalian Chromosomal Aberration Test. TG 473. Adopted: 26 September 2014

23. OECD Guideline for the Testing of Chemicals: Mammalian Bone Marrow Chromosomal Aberration Test. TG 475 Adopted: 26 September 2014.

24. Lloyd M, Kidd D (2012) The mouse lymphoma assay. Methods Mol Biol 817 $35-54$.

25. Yamamoto KI, Kikuchi $Y$ (1980) A comparison of diameters of micronucle induced by clastogens and by spindle poisons. Mutat Res 71: 127-131.

26. Decordier I, Kirsch-Volders M (2013) Fluorescence in situ hybridization (FISH) technique for the micronucleus test. Mol Biol 1044: 237-244.

27. Fenech M (2007) Cytokinesis-block micronucleus cytome assay. Nat Protoc 2: $1084-1104$

28. Singh NP, McCoy MT, Tice RR, Schneider EL (1988) A simple technique for quantification of low levels of DNA damage in individual cells. Exp Cell Res 175: 184-191.

29. Tice RR, Agurell E, Anderson D, Burlinson B, Hartmann A, et al. (2000) Single cell gel/comet assay: guidelines for in vitro and in vivo genetic toxicology testing. Environ Mol Mutagen 35: 206-221.

30. Reeser D (2013) Natural versus synthetic chemicals is a gray matter. Scientific American/The Guardian. 